\title{
From school to work: Coherence between learning in school and learning in workplaces for apprentices in the Media graphics programme in Norway
}

\author{
Nina Aakernes \\ OsloMet - Oslo Metropolitan University, Norway (ninaa@oslomet.no)
}

\begin{abstract}
A key challenge in vocational education and training (VET) programmes is the lack of coherence between the school-based and the enterprise-based parts of learning. This study explores the conditions that are important for the perception of coherence between learning in school and workplaces by interviewing apprentices enrolled in the Media graphics programme in Norway. In addition to the views of apprentices, the study also includes the perspectives of other participants in the vocational education system, such as media teachers and instructors in the workplaces and apprenticeship training office. The interview data revealed that the media education in school had facilitated the students' learning primarily by allowing them to work on authentic media productions. Despite this, however, some of the apprentices experienced a lack of coherence between learning in school and learning in enterprises, mainly because there were few opportunities to specialise in their chosen vocation in school, and limited cooperation between schools and workplaces about placement periods.
\end{abstract}

Keywords: practice-based learning in VET, apprenticeship, school-based learning, coherence in VET, vocational media education, media production 


\section{Introduction}

\section{Background and research question}

Coherence is acknowledged as an aspect of the field of education that influences learner outcomes (Canrinus, Bergem, Klette \& Hammerness, 2017). The concept of coherence has been defined as 'student's experience of meaningful relationships between the various aspects of professional knowledge and skills emphasised in different learning contexts' (Heggen, Smeby \& Vågan, 2015, p. 75). In the context of vocational education and training (VET), coherent education refers to an education where apprentices have opportunities to develop vocational competencies through working on authentic tasks from their chosen vocation both in school and workplaces (Hiim, 2017).

A number of recent studies have examined the challenges in learners' development of vocational competencies due to the lack of an experienced meaningful relationship between school-based learning and workplace learning in VET (for example Aarkrog, 2011; Hiim, 2013; Schaap, Baartman \& Bruijn, 2012; Tanggaard, 2007). Within the research literature, there are different approaches to these challenges. Some scholars focus on the concept of transfer, i.e. how to use what is learned in previous situations in new situations (for example Kilbrink \& Bjurulf, 2013; Aarkrog, 2011). There is also emerging research referring to the concept of boundary crossing and how students experience meaning and relationship in their education as they move between different learning contexts with different logics, i.e. school and workplace (for example Akkerman \& Bakker, 2012; Tanggaard, 2007). To emphasise the importance of investigating how to enhance the quality of VET by bridging the gap between school-based and enterprise-based education, the concept of coherence is chosen for this article (Canrinus et al., 2017; Heggen et al., 2015). This article contributes to the existing literature by studying apprentices' perceptions of coherence between school-based and enterprisebased education for apprentices in the Media graphics programme in Norway.

This programme is interesting for exploring perceptions of coherence because the school programme, Media and communication, has emphasised students' learning through working on authentic media production in the school-based part of the programme (Amdam, 2016b; Erstad, Gilje \& de Lange, 2007). Thus, one might expect that this programme would have fewer challenges related to coherence than many other programmes that do not have the same strong focus on vocational training in a school context. However, a recent survey conducted by the Norwegian Directorate for Education and Training (Utdanningsdirektoratet, 2016a) showed that apprentices do not feel that this practiceoriented school-based education prepares them well for the apprenticeship period. The survey measured satisfaction with school-based training as preparation for the apprenticeship period among apprentices in all vocational programmes in Norway. The results showed that the apprentices from Media and 
communication were the least satisfied of all the apprentices enrolled in various programmes.

No previous study has explored possible reasons for these results related to an underlying lack of experienced coherence between learning in school and learning in enterprises for apprentices in this programme. Furthermore, given that Norwegian VET is expected to undergo changes in the coming years, it is important to study an existing apprenticeship programme within the media field. This study explores the transition from school to work for apprentices in the Media graphics programme, and it closely examines the conditions that are important for the experience of coherence between the school-based and the enterprise-based parts of learning. Thus, the research question that guides the study is as follows:

- Which conditions are important for the perception of coherence between learning in school and learning in the workplace for apprentices in the Media graphics programme in Norway?

To answer this question, the article draws on in-depth interviews with six apprentices in different media enterprises, their instructors in these enterprises, two instructors in the apprentice training office ${ }^{1}$, and seven of the apprentices' former media teachers in four different schools.

\section{The Norwegian education programme for Media and communication}

The standard VET model in Norwegian upper secondary education consists of two years of school-based training followed by two years of apprenticeship training at an approved training enterprise. The school-based part of VET offers nine different programmes, and the subjects are divided into common core subjects, such as mathematics and Norwegian; common programme subjects, consisting of both theory-based teaching and vocational training in school workshops; and the vocational in-depth study project. The latter was introduced in 2006 as a part of the Knowledge Promotion Reform, and it is primarily meant to be carried out in enterprises - for specialisation in a particular trade with a relevant vocational practice (Utdanningsdirektoratet, 2016b). The national curriculum outlines the requirements for the two years of enterprise-based training, and after the apprenticeship period, apprentices appear for a final practical examination, normally carried out over five working days, to earn the Journeyman's Certificate in the trade (Utdanningsdirektoratet, 2008).

Media and communication (MC) falls into a hybrid category between the academic and vocational programmes in the Norwegian education system (Amdam, 2016a). The purpose of the school-based part of the programme is to qualify the students for either two years of apprenticeship in an enterprise, or after a third year in school, for further media education in colleges or universities. The curriculum covers competencies in communication, design, and production within 
different genres and fields: photography, film, graphic design for print and the web, multimedia, and sound (Utdanningsdirektoratet, 2007). Apprenticeships can be pursued in two programmes: Media graphics or Photography. This study focuses on the experiences of apprentices in the Media graphics programme.

Media graphics provides opportunities for apprenticeships in traditional prepress enterprises, advertising agencies, web or digital media firms, and film production companies (Medielarling.no, 2018). Because of rapid technological developments, the traditional distinctions between vocations in the pre-press field or between graphic design for print and different digital platforms have blurred or disappeared. Hence, the work tasks of a media graphics artist can include the layout and design of advertising materials, magazines and websites, editing of still or motion pictures, and practical work on film sets. The curriculum includes competencies in communication, business culture and concept, design, and production. There is a heavy emphasis on working with various types of software for design and production.

\section{Previous research related to coherence in VET}

Despite the different models for VET in the European countries, there are similar challenges due to a gap between the school-based and the enterprise-based parts of learning. The lack of coordination between learning in school and learning in the workplace often results in an inefficient transition from school-based education to work (Littke \& Thång, 2015, p. 7). In previous research, different scholars have revealed different aspects of coherence-related challenges. Recently, Gessler (2017) and Louw (2017) pointed to the lack of cooperation between schools and workplaces in the German and Danish dual apprentice system. Louw's study showed that closer cooperation between the teachers in schools and the instructors in the workplaces enhanced the students' experience of the relationship between the learning arenas.

According to Schaap et al. (2012), it is difficult for students to combine learning in vocational schools and workplaces. These difficulties stem from the differences in learning environments, where vocational schools are primarily focused on students' learning processes, and workplaces are mainly concerned with working and making profit (p. 100). According to Tanggaard, the apprentices' complaints of lack of coordination of learning in vocational schools and workplaces are due to their experiences of the learning environments as 'very dissimilar contexts with different norms and guidelines for action' (2007, p. 453).

However, Berner (2010) argues that this perspective provides a too narrow view of the school-based training in VET. Important reasons for Berner's point of view are the facts that VET teachers have extensive workplace experience and that the training is work-oriented and consists of 'interactions between teachers and students and tools and machines' (p. 28). Persson Thunqvist \& Axelsson 
(2012) have investigated the hybrid form of school-based vocational training in the Swedish vocational media programme. In order to prepare the students for the professional world of work the teachers organised the learning as work-like collective media production projects and invited professionals into school to take part in the student's productions. The researchers found that this educational practice brought work-life traditions into school. This way of organising the education in school as work-like production projects has similarities with the organising in the Norwegian Media and communication where students learn through work with authentic media productions (Amdam, 2016b; Erstad et al., 2007).

Several studies have highlighted the special coherence-related challenges in the Norwegian VET system because of the broad nature of the vocational education programmes (for example Dahlback, Hansen, Haaland \& Sylte, 2011; Hiim, 2015). These extensive programmes shape school-based education such that it results in insufficient opportunities for the students to specialise in their chosen vocation. Students, thus, experience a lack of specific qualifications relevant to their chosen apprenticeship after the two years of school-based education. There are, however, differences between vocational programmes and vocations (Dahl, Buland, Mordal \& Aaslid, 2012; Hansen \& Haaland, 2015). Research has shown that an important condition for coherence between learning in school and learning in the workplace in Norwegian VET is the opportunity for vocational practice in enterprises in the form of placement periods during the school-based part of the education (Hiim, 2013). Furthermore, assignments in school that are closely related to the experiences from the placement periods are of great importance (Dahlback et al., 2011; Hiim, 2013).

In summary, previous research suggests that a closer examination of coherence between learning in schools and workplaces is needed to enhance the quality of VET. This article addresses coherence in VET related to apprentices' transition from school to work in the Norwegian Media graphics programme.

\section{Coherence in VET and vocational competence}

The concepts of coherence and vocational competence are central to this study and are considered closely linked. Thus, coherence between learning in school and in the workplace can be seen as necessary for students' development of vocational competence (Heggen et al., 2015; Hiim, 2017). Heggen et al. (2015, p. 72) distinguish among biographic coherence, programme coherence and transitional coherence. Biographic coherence is understood as the extent to which learning in VET is promoted by previous experiences (p. 79). Programme coherence refers to how students experience the relationship between the different subjects in education, vocational theory and practice, and between the learning settings, for example during placement periods and at school (p. 80). Transitional coherence is 
understood as the relationship between the school-based part of the education and the expected requirements at workplaces (p. 82). The distinctions among the three different types of coherence can give a better understanding of the conditions important for the students' experiences of coherence between learning in school and in the workplace.

Given that the purpose of this article is to investigate the coherence between learning in school and in the workplace, the main focus is on transitional coherence. Moreover, programme coherence, i.e. a close relationship between the different parts of the school-based education, will be expected to also ensure better transitional coherence. A challenge to programme coherence in Norwegian vocational schools, is that the national curriculum framework divides comprehensive vocational competence into different school subjects and into theory and practice (Utdanningsdirektoratet, 2007). If the subjects are taught separately, the students might not grasp the relationship between different parts of the education such as the theoretical explanation of the communication model and the practical work on the design of media productions for a specific target group. Furthermore, in the practical work on an advertising poster, there are no strict limits between design and production, but in the curriculum design and production are two different subjects (Utdanningsdirektoratet, 2007).

The use of project-based educational practices, as researchers found in the Swedish and Norwegian vocational media education, seems to be a way to make the students' experience of the education more coherent (Amdam, 2016b; Erstad et al., 2007; Persson Thunqvist \& Axelsson, 2012). This kind of education can bridge the gap between the different subjects and between theory and practice in ways that strengthen programme coherence. Additionally, a school-based education that allows the students to work with authentic production can be considered to prepare the students for work-life, ensure transitional coherence, and stimulate students' development of vocational competence (Billett, 2001; Dreyfus \& Dreyfus, 1988; Schön, 1995).

Heggen et al. (2015) emphasise that transitional coherence is not merely concerned with how competence learned in the educational setting in schools is relevant to the qualifications requirements in the workplaces. Their point of departure is that what is learned in one context is difficult to transfer to another context without further learning. Thus, what is important for the experience of transitional coherence is the connection between the learning process in the school setting, and both the qualification requirements and further learning processes in the workplace.

The study is also inspired by scholars who have analysed vocational competence and investigated how this competence is developed (Billett, 2001; Dreyfus \& Dreyfus, 1988; Hiim \& Hippe, 2001; Schön, 1995). What these scholars have in common is that they are associated with a pragmatic epistemic tradition. In this tradition, vocational competence is regarded as holistic, including practical skills, 
theoretical knowledge, gestic knowledge, tacit dimensions and social competences such as accountability towards customers. The theory and practice are understood as closely linked together. According to Schön, the practitioner's competence or know-how is activated in action and is what he calls 'knowing in action' (Schön, 1995).

In order to develop holistic vocational competence, the students must have the opportunity to learn from experience by performing authentic tasks that are central to their chosen vocation. From a pragmatic perspective, realistic work experience is essential, preferably through regular placement periods in a vocational enterprise during the school-based part of the education (Billett, 2001; Dreyfus \& Dreyfus, 1988; Hiim \& Hippe, 2001; Schön, 1995). At its best, vocational schools allow the students to develop vocational competence through trial and error, reflection, discussion and guidance from fellow students and teachers with relevant work experience (Berner, 2010; Schön, 1987, 1995). In such a 'reflective practicum' (Schön, 1987), the students will learn 'how' (Dreyfus \& Dreyfus, 1988; Ryle, 2009) to use the principle from the communication model through work on the design of media production for a specific target group. By reflection and discussions on different solutions they will be able to experience the coherence between theoretical knowledge and practical performance (Schön, 1987, 1995). The development of vocational competence also requires that students have opportunities for personal involvement in the actual work tasks and experience a gradual increase of responsibility (Dreyfus \& Dreyfus, 1988).

Learning a vocation requires both being able to perform routine tasks and using the competence in new situations (Billett, 2001; Dreyfus \& Dreyfus, 1988). One of the challenges with the school-based part of education is that the students lack opportunities to learn through engagement in routine tasks (Billett, 2001, p. 25). In the Norwegian educational context, with broad vocational programmes that are intended to prepare students for many specialised vocations, few opportunities exist to repeat tasks or at times even to engage in a sufficient variety of tasks for a particular vocation. Consequently, the students may experience the school-based part of the education as disconnected and as lacking coherence with their chosen vocation.

To sum up, to develop vocational competence, it is important that the students experience coherence in their education, both within the school and between the school-based and enterprise-based parts of vocational programmes.

\section{Methods}

A qualitative design approach was used to acquire an in-depth understanding of the research question (Creswell, 2013), and the method of data collection was semi-structured interviews (Brinkmann \& Kvale, 2015). This article is based on data collected in 2015 and 2016 during two periods of the apprenticeship training 
period. The study mainly focuses on the experiences of the six apprentices. However, to supplement the experiences of the apprentices, it was important to include the perspectives of the other participants in the vocational education system. Hence, the study also included seven media teachers, six instructors in the apprentices' workplaces and two representatives of the apprenticeship training office.

The printing industry and pre-press enterprises have long traditions of apprenticeship; however, today, apprenticeships are also found in film and multimedia enterprises. Thus, the sampling of the apprentices was purposeful (Patton, 2015), to ensure that the selected participants had secured apprenticeships in workplaces that covered film production, traditional pre-press, advertising agencies and production both for print and digital platforms. The six apprentices had completed two or three years of the education programme Media and communication in different upper secondary schools before they entered the apprenticeship. The seven media teachers selected were those who taught the main media subjects in the last year of the apprentices' school-based education. The instructors in the enterprises were the persons responsible for the apprentices' learning during the apprenticeship period, and the instructors in the apprentice training office were responsible for both the contract between the apprentices and the media enterprises, and for several courses that the apprentices enrolled in during the apprenticeship period. The study follows the Norwegian guidelines (Norwegian Centre for Research Data, 2017) regarding matters as consent, confidentiality, information provided to participants, and the use of data.

The first part of the data collection consisted of interviews with the apprentices and the media teachers. These interviews were conducted when the apprentices had secured a contracted apprenticeship with the enterprises. Three of the apprentices had been working in the enterprise for a couple of weeks; the other four had not yet started working at the time of the interviews. The primary objective of these interviews was to discover how the school-based learning had been organised, and why the students had chosen to become apprentices.

The second part of the data collection consisted of interviews with the apprentices and the instructors in the workplaces. This part of the study was conducted during the first six months of the apprenticeship period. The primary focus of this part was the coherence between learning in school and learning in workplaces. Furthermore, an interview was conducted with two representatives from the apprenticeship training office. Semi-structured interview guides were used to give a framework for all the interviews (Brinkmann \& Kvale, 2015). Previous research and the theoretical background of the study were used as a framework for the interview guides. For the second part of the data collection, the memos and results from the first part were also used.

All the interviews were carried out by the author. The interviews were recorded digitally and fully transcribed before they were analysed. First, I read each 
interview and noted the points that struck me as important. From these notes, I wrote memos of each interview. Next, each interview was read thoroughly and coded in accordance with the open coding principles (Merriam \& Tisdell, 2016), using Atlas.ti. During this part of the analysis, I wrote new memos. Finally, the codes were organised into categories (Creswell, 2013; Merriam \& Tisdell, 2016). While defining the categories, I used a combination of 'top down' (by using categories from previous research and the theoretical background of the study) and 'bottom up' (by developing analytic categories from the codes and memos) approaches (LeCompte \& Schensul, 2012).

While the students' experiences of coherence in their education formed the main focus of the analyses, the interviews with the other participants were analysed to get a more extensive understanding of the research question. The interviews with the teachers provided knowledge about how the teachers experienced the educational practice and the school system. Furthermore, the interviews with the instructors provided knowledge concerning the instructors' expectations regarding the apprentices' competence and their opinion of the quality of the school-based education as a preparation for the apprenticeship period.

Finally, three main categories were identified: (a) school-based education focusing on authentic tasks that are essential for the student's chosen vocation; (b) placement periods in the school-based part of education; and (c) work with real media productions for customers in school. Each of these categories is discussed separately in the next section. To ensure participant anonymity, the pronoun 'she' has been used for all the participants.

\section{Conditions that are important for the perception of coherence be- tween learning in school and at the workplace}

\section{School-based education focusing on authentic tasks that are essential for the student's chosen vocation}

The apprentices had mainly experienced school-based education without clear segregation between vocational theory and practice. Apprentice 5 explained, 'The theory was integrated into the media production projects, so we got the theoretical input during the practical work.' The apprentices also emphasised that their timetable did not have any set times in the week for the three different programme subjects: communication, design and production. Apprentice 1 said, 'The timetable just says media and communications, and the various subjects are within that.' Furthermore, the responses suggested that the apprentices experienced working with media productions as a comprehensive task and found it difficult to distinguish between the three programme subjects. Apprentice 1 added, 'It was when we got the assessment of the assignments that we saw that we had been assessed on three different subjects.' By way of explanation, Teacher 
2 said, 'It is always a little difficult to explain the differences between the three (subjects), because they are closely linked in practical production.' Thus, the students engaged in real media production in the school-based part of the education did not understand that comprehensive vocational competence was divided into three different subjects in the curriculum.

Despite the focus on media production work in school, some of the apprentices found it difficult to see the coherence between the school-based and the enterprise-based parts of the education. Apprentice 2 compared the experience of working as an apprentice with working on assignments in school: 'I don't think it is very similar. / .../ The assignments we had in school were more like making a brochure only one time, and then we didn't need to know efficient ways of working. However, now we have to focus more on efficiency because we often make similar products.' The students did not have opportunities to learn to work efficiently on routine tasks in school. Instructor 2 in the apprentice training office said, 'You don't get the students into making efficient templates for swift production because in school they make things only once. /.../ There is a lot of stuff they are undergoing.' The broad nature of the curriculum did not enable students to learn by repeatedly working on the same production tasks in school.

The school also did not induce the same feelings of accountability that the apprentices experienced in their workplaces. Apprentice 6 said,

In school, I felt that you are not held accountable for things that might be wrong because it affects you and nobody else. However, in a workplace, if you make a mistake, it might affect your colleagues, and you have a great responsibility because the product is to be delivered to a customer, and not just to the teacher.

The apprentice viewed the level of accountability she had towards customers as a significant differentiating condition between the school and workplace. Without a sense of accountability towards others in school, students may find it difficult to see the coherence between the purpose of the media production in school and that at workplaces.

The broad nature of media education in school was also experienced as a challenge. Several of the apprentices were not offered the opportunity to develop specific vocational qualifications that were important for their chosen vocation. Apprentice 2 said,

\footnotetext{
I think it is a pity in a way, in school /.../ that you cannot choose /.../ I remember we had to work with photography and film and sound, and I thought it was the most pointless in the world, because I only wanted to work with graphic design, because I knew what I wanted to do later. / ... / I think, in a way, that the other vocations took too much time, we had to make films and reportages and such things.
}

The responses showed that the degree to which the apprentices had the opportunity to specialise in their chosen vocation differed between schools. Talking about her school-based education, Apprentice 3 said that in her school there had been opportunities to relate the assignments to one's own choice of specialisation, 
'We had more like a case, really /.../ so then we could produce for example a newspaper article, a commercial, a short film, design something, take a photograph or make a logo.' The instructors also identified the broad curriculum for the school-based education as a hindrance to specialisation in specific vocations. Instructor 4 said, 'MC includes so many vocational directions' while Instructor 5 said, 'They (the students) don't really become very good at anything particular.'

The interviews showed that the professional background of the teachers strongly influenced students' opportunities to work on authentic assignments in school as well as their ability to specialise in their chosen vocation. Apprentice 5 said, 'The school has been very good at facilitating assignments that let us work as we eventually will do later. Now that I am an apprentice, I notice I use the things I learned in school.' Later in the interview, she said, 'Yes, we were so lucky that we had teachers with special qualifications in every vocation, so if we worked on a campaign, those who worked with graphic design could discuss with the graphic design teacher.' Apprentice 4, who pursued her apprenticeship in graphic design, was not so 'lucky' with the vocational background of her teachers, as she explained, 'Some of them had experience from the national broadcasting, working with film and sound productions, actually.' Later in the interview, she added,

\footnotetext{
The only graphic design work was to create the layout and do an interview for a magazine. That was what we did in InDesign (the publishing software), so there was not so much graphic design. There was not much of the kind of work I do here (in the workplace as an apprentice) in MC, actually.
}

This response indicates that in the apprentice's school, the journalistic tasks involved in a magazine project were considered more important by the teachers than working with the layout and templates and learning how to make files ready for printing, which are important vocational competences for a graphic designer. In broad Norwegian VET programmes, it is difficult to form teacher teams that cover all the vocations within the programme. Consequently, Apprentice 5 considered herself 'lucky' for having teachers with specialised vocational competence and background related to her choice of vocation.

The regulations for the practical exam in the second year of school were interpreted differently both by schools and also by other departments in the education system. In some schools, the students could choose from among various productions. Thus, for example, those who had specialised in film production were given the opportunity to make a film for the exam. In other schools, no such choice was available. In the context of interpreting exam regulations, Teacher 2 discussed the practice of asking the students to draw lots to determine their media production:

We talked with the exam panel, and we talked a lot with the people at the Examination Office about whether the exam has to be as it is now - where it is your luck or the draw that decides what you may come up with. Or is it possible to give the 
From school to work: Coherence between learning in school and learning in workplaces

students a case, and let them choose what kind of media production they want to make? This would have been fairer. However, this was not possible here, even if it has been done in other places.

Even though the teachers preferred to let the students specialise in their chosen vocations, they did not modify the education design accordingly because the exam regulations were interpreted to mean that all the students should be prepared for any media production in the final exam.

To sum up, the interviews showed that the apprentices received opportunities to work on actual media productions in the school-based part of their education. Furthermore, they experienced coherence between theory and practice and between the media subjects. Thus, their experiences of programme coherence were strong. However, the experience of transitional coherence varied depending on the apprentices' opportunities to specialise in their chosen vocation. The main reasons for these varying opportunities were the vocational background of the teachers and the differences in the interpretation of the practical exam regulations. Apprentices who had the opportunity to specialise experienced better transitional coherence than the others. One could also say that bibliographic coherence increased with opportunities to specialise, because the education was more in accordance with the students' personal interests and future plans.

\section{Placement periods in the school-based part of education}

In Media and communication, the curriculum goal of enabling learning through placement in enterprises during the school-based part of the education was only minimally accomplished. For instance, Apprentice 5's school did not offer placement options. She said, 'I haven't had a placement.' Researcher: 'Was it a possibility?' Apprentice 5: 'No, not in MC.'

Only two apprentices had experienced placement during the school-based part of their education. During the placement, Apprentice 6 found that the working style in the media enterprise was different from what she had learned in school: 'I think the way of working was much more efficient in the placement. The way of working in the school was slow compared to what we could have learned / ... / because we used other methods that took a lot of time.' The term 'other methods' referred to design templates used at workplaces for magazines and other productions that enabled efficient and fast output; such templates were not used in the school. In this case, the school did not use a professional approach because it lacked teachers with a specific vocational background. The apprentice explained, 'We were short on teachers, and I think that was the main reason for not learning professional ways of working in some vocations.'

For Apprentice 3, the placement period in the first year of school was crucial for her choice of apprenticeship. She found the way of working in the enterprise different and more interesting than what she had experienced in school: 'I decided it (the apprenticeship) in the first year (of school) because I had placement 
and the way of working was entirely different from school.' She found that the technical approach to work was different, for example, 'even if different enterprises use the same software, there are variations in the way of using the settings'. She also highlighted the difference in 'atmosphere'. In the context, 'atmosphere' referred to the difference between a school setting where all the students are of the same age, versus a work setting where there are co-workers of different ages. 'In a workplace you can joke with your colleagues / .../ for a teacher you are just one of twenty others that do the same task.' A drawback for students lacking placement opportunities is that they do not experience what it is really like to work with their chosen vocation or the social structure in a workplace.

The teachers often found it difficult to organise placements. Teacher 7 said, 'It's difficult, there is a hectic life out there (in the media enterprises).' The instructors from the apprentice training office reported that the enterprises did not have a favourable attitude towards placement periods. One said, 'It is tough to organise placement periods in enterprises because of the high number of applicants.' The other continued, 'Some enterprises get many telephone calls from students that offer to work for free.' The word 'students' in the latter sentence referred to students from media education programmes at the university and college level. The fact that students from upper secondary schools had to compete with these senior students for the placement positions made it difficult to organise placements during the school-based part of the education.

A lack of formalised cooperation between media enterprises and the upper secondary schools characterised the placement problem. Most placements were the result of a strong initiative from the student's end or occurred because teachers had contacts in the trade. Apprentice 6 explained how she got the placement position:

I went to (name of enterprise) very early to check out possibilities for apprenticeship. Then they offered me a placement position so that they could get to know me because they didn't know if they could take in an apprentice that year. However, I got this placement position so that they could get to know me, and I could learn about the way of working, and eventually get an apprenticeship later.

Teacher 4 explained how the teachers tried to help with placement positions:

The rule is that the students shall provide the placement positions. /.../ However, I understand who's motivated, who might have tried and not succeeded anywhere. /.../ We know of some enterprises that usually hire apprentices, and we give a hint, 'You can try to get a placement there.'

While the teachers struggled to organise placement periods, responses from some of the instructors suggested that their enterprises were open to placements. Instructor 2 reflected on the possibility of placement periods in her workplace:

For students to come and perform work assignments here, let's say for a week, you know, it could have gone well. / .../ Because I'm instructing the apprentices, and the two apprentices are learning from each other, so here it would have been feasible, really. 
Instructor 1 also considered placement a possibility in her enterprise, even though she emphasised that she would not take the initiative. She said, 'If I had been asked, I would have considered it (placement).' The responses suggest that while media enterprises are open to possibilities of better cooperation for placement periods, the initiative has to be taken by the schools or the apprentice training office.

To sum up, the results showed that teachers considered it difficult to arrange placement periods in MC, and very few students had experienced placements. Thus, many of the students lacked the real experience of working in their chosen vocation during the school-based part of the education. This lack of experience led to lack of coherence between the school-based and enterprise-based part of the education. However, the students who had experienced a placement reported that there was a gap between ways of production at school and at the work place. This gap indicates that a placement in itself is not enough to create coherence; there must also be active cooperation between schools and enterprises. Formalised cooperation between schools and workplaces over placements in MC seems to be very limited, though responses pointed to the potential for better cooperation.

\section{Work on real media productions for customers in school}

In some schools, the teachers allowed students to work on productions intended for customers. Apprentice 2 said that she considered working for clients in school as real production:

\footnotetext{
It is in a way like a real job, because we have companies or customers. They contact the teacher, and he hands out the jobs, or we decide among ourselves who is going to do what, and then we keep in touch with them, and we finish media productions and so forth.
}

The way of cooperation on distributing the different jobs in this school gave the students an opportunity to engage in assignments close to their interests and chosen vocation. The same apprentice also reflected on how the experience of working on media productions for customers in school contributed to her choice of apprenticeship.

In a way, the assignments weren't only made up. We had contact with real customers, and I found this much more exciting, and I think this is the reason for the choice /.../ I started to understand that I might become an apprentice.

Teacher 3 discussed how working with real clients was crucial to help students understand the importance of deadlines.

The customer who came by a fortnight ago, he says this is not quite right. /.../

You have to correct it. OK, could you come back next Thursday, the student says.

Next Thursday! I need this for a meeting at 3 pm today. So, it becomes very realistic for them, and this is very positive, and it makes them grow up. I don't think we could have done things like this if we had been a traditional school. 
This response showed that the teacher looked upon working with real customers as something different from a traditional school. A traditional school is often seen as focusing on particular subjects, grades and exam performance, while Teacher 3 focused on qualifications essential to the trade: 'We endeavour to help them master what working life needs.' Thus, the teacher also attempted to impart competences such as communication with customers and meeting deadlines in the school-based part of the education.

The fact that these productions were to be used outside school allowed the students to experience what it is like to work with real media productions. Apprentice 5 said, 'It was exciting because we knew that we were making a product that was going to be used in the real world.' According to Teacher 4, letting students work with real customers helped them realise that the media productions would ultimately be used in the real world: 'So, I think this is very valuable learning, the fact that the learners have to realise that others are going to use this, and they get an assessment from professionals.'

In the schools where the students made media productions for real customers, the teachers were responsible for organising and facilitating the contact between the customers and the students: 'So, we can get things started. Now we arrange this meeting, and next time you contact the customer and only keep me posted.' In contrast, Apprentice 1 from another school spoke about how they were told to approach clients but without any guidance:

\footnotetext{
I think we found it a bit scary because we didn't know who the customers were or what we should do. Thus, nobody wanted to do this, I remember. That was a pity because it would have given us the possibility to experience what it is like to work for real customers.
}

This quote shows that for a 17-year-old, approaching potential customers can be an overwhelming task.

To sum up, the study responses indicate that working on real productions for customers in schools gives the students an opportunity to develop a certain degree of relevant vocational practice. This education practice brings work-life traditions into school, prepares the students for qualification requirements in the workplaces, and increases coherence between learning in school and in the workplace. Furthermore, this education practice can serve as a valuable basis for choosing a vocation. However, it is important that such opportunities are organised by the school or teachers, and that the students are allowed to work on media productions central to their chosen vocation.

\section{Concluding discussion}

The study attempted to answer the following research question: What conditions are important for the perception of coherence between learning in school and in the workplace for apprentices in the Media graphics programme in Norway? 
The material in this study suggests that the following two conditions are particularly important: 1) the availability of practical education in school with possibilities for students to engage in authentic tasks that are essential to their chosen vocation, and 2) cooperation between schools and workplaces for placement periods in the school-based part of the education. These findings confirm what we know from previous research and the literature about coherence and the development of vocational competence in VET. What is more surprising is how weakly these conditions are fulfilled in the education programme for Media and communication.

From the results, I conclude that the apprentices in the study experienced a school-based education that heavily emphasised production of media material. These results are in agreement with the findings of Amdam (2016b) and Erstad et al. (2007). The school-based part of the education has good programme coherence (Heggen et al., 2015, p. 80) by focusing on the relationship between theory and practice and the different media subjects in the curriculum.

However, programme coherence and vocational training in school is no guarantee of transitional coherence - coherence between the school-based and the enterprise-based parts of education. The scope of specialisation in the students' chosen vocation during the school-based part of education is a key condition for the experience of transitional coherence. The apprentices interviewed had unequal opportunities for specialisation and these opportunities differed greatly across schools. Thus, it was random who were given the opportunity to specialise in their chosen vocation.

Some of the apprentices had experienced working on authentic media productions, but not in their chosen vocation; hence, they found it difficult to see the coherence in their education. These apprentices did not complain about schoolbased education focusing too heavily on theoretical knowledge, they complained about having to do media production work in other vocations than their chosen one. These findings are in accordance with those reported in previous research: in some vocational programmes it is not the amount of theory that creates problems of coherence (for example Hansen \& Haaland, 2015) but whether the students experience a meaningful relationship between both the theory and practice in school and their chosen vocation.

Other apprentices received a school-based education with opportunities for specialisation and learning through work on authentic tasks, as performed in their chosen vocations (Dreyfus \& Dreyfus, 1988; Schön, 1995). This educational practice has much in common with learning in a reflective practicum (Schön, 1987). Those who experienced the best coherence between this way of learning in school and learning in the workplace were those who were given the opportunity to work on real media production for customers in school.

Such project-based education, which also seems common in Swedish media education (Persson Thunqvist \& Axelsson, 2012), brings the expectations and the 
qualification requirements from the world of work into school and ensures better transitional coherence. The results indicate that the apprentices' experience of personal involvement and accountability towards customers and colleagues is very important for their experience of differences and lack of coherence between the school-based and enterprise-based parts of education (Dreyfus \& Dreyfus, 1988). This is an example of how schools and workplaces have different practices, and differences in what is considered important (Schaap et al., 2012; Tanggaard, 2007; Aarkrog, 2011). A hybrid education practice where the expectations from the professional world of work are brought into school (Persson Thunqvist \& Axelsson, 2012) can bridge the gap between school and the workplace and ensure better transitional coherence. However, the contact with customers can be challenging for young students and must be well prepared and facilitated by the teachers.

Results point to two particular reasons why apprentices did not have the opportunity to specialise in their chosen vocation during the school-based part of the education. The first reason is the school's approach to the practical exam in the second year of school - whether the school allowed students to choose among various assignments or asked them to draw lots. These results reflect the problems associated with different interpretations of the exam regulations, as in other Norwegian vocational programmes (Dahlback et al., 2011; Hiim, 2013).

The second reason is that the apprentices did not have access to teachers with work experience from their chosen trade. Thus, the students did not receive proper guidance in their vocation or opportunities to work on authentic assignments for their chosen vocations. Again, these findings support previous research that broad Norwegian VET programmes make it difficult to establish teacher teams with the relevant background for all the vocations (for example Dahlback et al., 2011; Dahlback, Hansen, Haaland, \& Vagle, 2015; Hansen, 2017).

Challenges concerning transitional coherence are also related to methods of working on school assignments that did not match the methods used at the workplaces. One reason for this mismatch is the lack of teachers with relevant work experience. Another reason is that schools offer little time for, or rarely emphasise, repeatedly working on the same productions or working on routine tasks (Billett, 2001). As a result, the students do not learn efficient ways of working, for example, with templates. This is an example of how workplaces provide experiences and learning opportunities that are difficult to simulate in a school setting (Heggen et al., 2015). Time to work with specialised tasks is important for apprentices' experience of coherence.

The lack of cooperation between schools and workplaces over placement periods during the school-based part of the education is a key concern. It prevents students from having work experiences in their chosen vocation before the start of their apprentice period. This means that they have no experienced work context that subjects and assignments in school can be related to. As a result, the 
transition from school to work as an apprentice becomes more difficult (Hiim, 2013). According to the results of this study, the collaboration between schools and workplaces in Media and communication seems to be especially weak compared with other Norwegian vocational programmes (Nyen \& Tønder, 2012). A reason for this may be the programme's focus is midway between vocational and academic (Amdam, 2016a). However, the results point to the potential for closer cooperation between schools and workplaces on placement periods. Such cooperation can ensure better coherence between the school-based and enterprisebased parts of education (Louw, 2017).

The findings from this relatively small-scale, qualitative study cannot be generalised to all VET programmes. Neither is it possible to draw any conclusions for all apprentices in the Media graphics programme. However, this investigation of the experiences of six apprentices contributes to a deeper understanding of the conditions important for coherence in VET and the development of vocational competence.

This study has shown that the conditions important for coherence between learning in school and at the workplace in the Media graphics programme in Norway differ greatly across schools. Thus, to enhance the quality of VET, the curriculum and regulations should be more explicit and not as open to subjective interpretation. Furthermore, cooperation between schools and workplaces, a key condition for the experience of coherence, ought to be pursed at a structural level and should not be dependent on the network of individual teachers. There is clearly a need for more research and development on coherence in the Media graphics programme and in VET generally. One interesting follow-up to this study would be to investigate the transition from school to work for apprentices who have received a school-based education in line with the conditions identified as important in this study. Such an investigation could further enhance the understanding of coherence and the development of vocational competence.

\section{Endnote}

${ }^{1}$ A training office is owned and driven by a community of companies. The office is an approved training establishment responsible for a two-year training contract with the apprentices. The training of apprentices is a shared responsibility between the company, where learning takes place, and the apprenticeship training office (Nore, 2015).

\section{Notes on contributor}

Nina Aakernes is a PhD candidate at the Department of Vocational Teacher Education at OsloMet - Oslo Metropolitan University, Norway. Her research interests focus on vocational learning in school and through apprenticeship, and curriculum development in vocational education. 


\section{References}

Aarkrog, V. (2011). A taxonomy for teaching transfer skills in the Danish VET system. Nordic Journal of Vocational Education and Training, 1(1), 1-13.

Akkerman, S., \& Bakker, A. (2011). Boundary crossing and boundary objects. Review of Educational Research, 81(2), 132-169.

Akkerman, S., \& Bakker, A. (2012). Crossing boundaries between school and work during apprenticeships. Studies in Vocational and Professional Education, 5(2), 153-173.

Amdam, S. (2016a). The dangers of having fun: Doing production work in school. In O. Erstad, K. Kumpulainen, Å. Mäkitalo, K.C. Schrøder, P. PruulmannVengerfeldt, \& T. Jóhannsdóttir (Eds.), Learning across contexts in the knowledge society (pp. 85-108). Rotterdam: SensePublishers.

Amdam, S. (2016b). Media education goes professional? Media teachers' self-image, positioning and educational focus. Nordicom Review, 37(2), 81-95.

Berner, B. (2010). Crossing boundaries and maintaining differences between school and industry: Forms of boundary-work in Swedish vocational education. Journal of Education and Work, 23(1), 27-42.

Billett, S. (2001). Learning in the workplace: Strategies for effective practice. Crows Nest, Australia: Allen \& Unwin.

Brinkmann, S., \& Kvale, S. (2015). InterViews: Learning the craft of qualitative research interviewing ( $3^{\text {rd }}$ ed.). Thousand Oaks, Calif.: Sage.

Canrinus, E.T., Bergem, O.K., Klette, K., \& Hammerness, K. (2017). Coherent teacher education programmes: Taking a student perspective. Journal of Curriculum Studies, 49(3), 313-333.

Creswell, J.W. (2013). Qualitative inquiry E research design: Choosing among five approaches ( $3^{\text {rd }}$ ed.). Los Angeles: Sage.

Dahl, T., Buland, T., Mordal, S., \& Aaslid, B.E. (2012). På de samme stier som før: Kunnskapsløftet i fag-og yrkesopplæringen [On the same paths as previously: The Knowledge Promotion Reform in VET]. Trondheim: SINTEF.

Dahlback, J., Hansen, K., Haaland, G., \& Sylte, A.L. (2011). Yrkesdidaktisk kunnskapsutvikling og implementering av nye læreplaner (KIP) [The development of new didactic knowledge and the implementation of a new curriculum] (Vol. 1/2011). Lillestrøm: Høgskolen i Akershus.

Dahlback, J., Hansen, K., Haaland, G., \& Vagle, I. (2015). Yrkesfaglærerens kompetanse $\mathrm{i}$ framtidens skole [The competence of the vocational teacher in the future school]. In K.H. Hansen, T.L. Hoel, \& G. Haaland (Eds.), Tett på yrkesopplxring: Yrkesrelevant, tilpasset og samfunnstjenlig? [Approching vocational education: Relevant, customised and beneficial?] (pp. 89-108). Bergen: Fagbokforlaget.

Dreyfus, H.L., \& Dreyfus, S.E. (1988). Mind over machine: The power of human intuition and expertise in the era of the computer. New York: Free Press. 
From school to work: Coherence between learning in school and learning in workplaces

Erstad, O., Gilje, Ø., \& de Lange, T. (2007). Re-mixing multimodal resources: Multiliteracies and digital production in Norwegian media education. Learning, Media and Technology, 32(2), 183-198.

Gessler, M. (2017). The lack of collaboration between companies and schools in the German dual apprenticeship system: Historical background and recent data. International Journal for Research in Vocational Education and Training, 4(2), 164-195.

Hansen, K.H. (2017). Hva er yrkesdidaktikk i dagens yrkesopplæring i skole? [What is vocational curriculum in today's school-based VET?]. Scandinavian Journal of Vocations in Development, 2, 1-25.

Hansen, K.H., \& Haaland, G. (2015). Utfordringer i norsk yrkesopplæring [Challenges in Norwegian vocational education]. In K.H. Hansen, T.L. Hoel, \& G. Haaland (Eds.), Tett på yrkesopplæring: Yrkesrelevant, tilpasset og samfunnstjenlig? [Approching vocational education: Relevant, customised and beneficial?] (pp. 19-49). Bergen: Fagbokforlaget.

Heggen, K., Smeby, J.-C., \& Vågan, A. (2015). Coherence: A longitudinal approach. In J.-C. Smeby \& M. Sutphen (Eds.), From vocational to professional education: Educating for social welfare (pp. 70-88). London: Routledge.

Hiim, H. (2013). Praksisbasert yrkesutdanning [Practice-based vocational education]. Oslo: Gyldendal akademisk.

Hiim, H. (2015). Kvalitet i yrkesutdanningen: Resultater fra et aksjonsforskningsprosjekt om yrkesforankring av innholdet i yrkesutdanningen [The quality of curriculum in VET: Results from an action-research project on content and structure in VET]. Norsk pedagogisk tidsskrift, 99(2), 136-148.

Hiim, H. (2017). Ensuring curriculum relevance in vocational education and training: Epistemological perspectives in a curriculum research rroject. International Journal for Research in Vocational Education and Training, 4(1), 1-19.

Hiim, H., \& Hippe, E. (2001). A utdanne profesjonelle yrkesutøvere [Educating professional practitioners]. Oslo: Gyldendal akademisk.

Kilbrink, N., \& Bjurulf, V. (2013). Transfer of knowledge in technical vocational education: A narrative study in Swedish upper secondary school. International Journal of Technology and Design Education, 23(3), 519-535.

LeCompte, M.D., \& Schensul, J. J. (2012). Analysis and interpretation of ethnographic data: A mixed methods approach (2nd ed.). Lanham: AltaMira Press.

Littke, K., \& Thång, P.-O. (2015). Learning at work in Higher Vocational Education. Nordic Journal of Vocational Education and Training, 5(1), 1-17.

Louw, A. (2017). Kobling mellem skole og praktik på erhvervsuddannelserne [The connection between school and practice in vocational education]. In K.E. Andreasen, \& H. Duch (Eds.), Forandringer i ungdomsuddannelserne: Overgange og indsatser (pp. 93-114). Aalborg: Aalborg Universitetsforlag.

Medielarling.no. Bli mediegrafiker. Retrieved 3. January, 2018, from http://medielarling.no/elever/mediegrafiker 
Merriam, S.B., \& Tisdell, E.J. (2016). Qualitative research: A guide to design and implementation $\left(4^{\text {th }}\right.$ ed.). San Fransisco: Jossey-Bass.

Nore, H. (2015). Re-contextualizing vocational didactics in Norwegian vocational education and training. International Journal for Research in Vocational Education and Training, 2(3), 182-194.

Norwegian Centre for Research Data. (2017). Information and consent. Retrieved 4. March, 2018, from http://www.nsd.uib.no/personvernombud/en/help/information_consent/ Nyen, T., \& Tønder, A.H. (2012). Fleksibilitet eller faglighet? En studie av innføringen av faget prosjekt til fordypning i Kunnskapsløftet [Flexibility or proficiency? A study of the implementation of the subject in-depth study in the Knowledge Promotion Reform]. Oslo: Fafo.

Patton, M.Q. (2015). Qualitative research \& evaluation methods: Integrating theory and practice (4 ${ }^{\text {th }}$ ed.). Los Angeles: Sage.

Persson Thunqvist, D., \& Axelsson, B. (2012). 'Now it's not school, it's for real!': Negotiated participation in media vocational training. Mind, Culture, and Activity, 19(1), 29-50.

Ryle, G. (2009). The concept of mind: 60th anniversary edition. New York: Routledge. Schön, D.A. (1987). Educating the reflective practitioner. San Francisco, Calif: JosseyBass.

Schön, D.A. (1995). The reflective practitioner: How professionals think in action. Aldershot: Arena.

Schaap, H., Baartman, L., \& Bruijn, E. (2012). Students' learning processes during school-based learning and workplace learning in vocational education: A review. Studies in Vocational and Professional Education, 5(2), 99-117.

Tanggaard, L. (2007). Learning at trade vocational school and learning at work: Boundary crossing in apprentices' everyday life. Journal of Education and Work, 20(5), 453-466.

Utdanningsdirektoratet. (2007). Programme area for media and communication: Curriculum for common programme subjects Vg2 (MED2-01). Retrieved 17. January, 2018, from https://www.udir.no/k106/MED2-01?lplang=http://data.udir.no/k106/eng

Utdanningsdirektoratet. (2008). Curriculum for media graphics VG3 / in-service training at a training establishment (MGR3-01). Retrieved 17 January, 2018, from https://www.udir.no/k106/MGR3-01?lplang=http:/ / data.udir.no/k106/eng

Utdanningsdirektoratet. (2016a). Lærlingeundersøkelsen [The apprentice survey]. Retrieved 10. August, 2017, from https://skoleporten.udir.no/rapportvisning/fag-og-yrkesopplaering/laeringsmiljoe/laerlingundersoekelsen $/$ nasjonalt?enhetsid $=00 \&$ vurderingsomrade $=6 \&$ underom$\underline{\text { rade }}=54 \&$ skoletype $=6 \&$ skoletypemenuid $=2 \&$ sammenstilling $=1$ 
From school to work: Coherence between learning in school and learning in workplaces

Utdanningsdirektoratet. (2016b). Norwegian vocational education and training (VET). Retrieved 17. January, 2018, from https://www.udir.no/in-english/norwegian-vocational-education-and-training/ 